\title{
Scholten, Jaap. 2016. Comrade Baron - A Journey through the Vanishing World of Transylvanian Aristocracy. Saint Helena, CA: Helena History Press. 404 pp.
}

\author{
Reviewed by Corina L. Petrescu, The University of Mississippi
}

Jaap Scholten is a Dutch writer and journalist living in Hungary since 2003 and Comrade Baron is his first non-fictional work. It was first published in Dutch in 2010 by Atlas Contact Press, won the Libris History Prize in 2011 and was shortlisted for the Bob den Uyl Prize for the best travel book of that same year. It then came out in 2013 in English by Corvina Publishing in a limited edition since, as the reader finds out in the "Note to the English Edition" of the 2016 book, the author had promised one of his informants that no Hungarian, Romanian or worldwide English editions of his book would be published for as long as she lived (15). Following this informant's death in 2014 the book was republished in 2016 by Helena History Press.

Comrade Baron examines a fascinating and under-investigated topic, which caught my attention as soon as I learned of the book's existence. It focuses on the lives of twenty-five members of the Transylvanian aristocracy of just before and after March 1949, the time when the new communist authorities of Romania -- to which Transylvania belonged in its entirety as of 1947 -- took drastic measures against all members of this social class. According to the author, he "sought out the descendants of the once mighty aristocratic families [of Transylvania] (...) to note down their stories, including what [he] suspect[ed] $\mathrm{m}$ [ight] be lies and distortions, fables, or attempts at mythmaking" (20) before these people died out and their history would be lost. Attempting to recreate the lost world of this aristocracy as well as sketch its life in the postcommunist era, the author traveled in the spring of 2009 and "several times" (26) later between Romania and Hungary to meet and interview elderly Transyilvanians who once had been the country's aristocracy. Given that he chose to present his findings in a non-fictional documentary work, I as one reader assumed that Scholten would at least try to present a perspective on his topic of interest that is as objective as possible; but that is not the case.

First, Scholten's use of the same place-names in both Hungarian and Romanian interchangeably is confusing despite the explanation that he "chose which [name] to use based on the context, so names mentioned to [him] in Hungarian are in Hungarian, while names in a Romanian context are in Romanian" (21). Multilingual people tend to use the generally accepted name of a place for the language in which they express themselves at a given time; for an English speaking audience, moreover, the officially accepted English names of places should have been used consistently to avoid confusion.

Secondly, the book is made up of three parts: "They Were Counted" (29-117), "They Were Divided" (119-269), and "They Were Found Wanting" (271-391). To the initiated reader, this structuring and naming make the book reminiscent of Miklós Bánffy's Transylvanian trilogy written in the 1930s and translated and published in English, winning great acclaim (it was

$($ (c) $)$ EY

ULIS D-Sente 
reviewed in the Washington Post, Times Literary Supplement, The Guardian and others), only in the 1990s. Whereas Bánffy's endeavor enchanted readers of nostalgic novels, Scholten's project lacks the critical distance required from a non-fictional work, although it is based on his Master thesis at Central European University, Budapest (2009), entitled From Ballroom to Basement: the Internal Exile of the Hungarian Aristocracy in Transylvania. Due to its academic grounding, the book has a first-rate bibliography, a chronological overview of historical events that occurred in Transylvania from 896 until 2007 with some references to Romanian and general EastEuropean history such as Stalin's death (1953) or the fall of the Berlin wall (1989), a glossary, and informative biographies of Scholten's informants, mostly members of Hungarian pre-First World War aristocracy, whom the author interviewed while working on his thesis. Yet, in his use of these same interviews in this book, this time largely without analysis, Scholten does not clarify to what extent he accepts or not the words of his interviewees, thus lending these testimonies an impressionistic character and making them sound strongly elegiac.

Thirdly, the author depicts this aristocracy as the bearer of traditions and the guarantor of stability, hence implying that its destruction under communism led to the moral and economic ruin of contemporary Hungary and Romania. Scholten claims that the aristocracy survived communism with dignity and without loss of its strong group-identity (156-163), which was simply preserved underground (188-198). The possibility that this aristocracy was itself corrupted is dismissed as communist propaganda rather than critically considered. The extent to which the aristocracy acted as a passive bystander of Miklós Horthy's regime or of the Holocaust of Hungarian Jews is far from explored in this book. Scholten likewise omits to discuss the collaboration of certain members of the aristocracy with the Hungarian secret police in either of its incarnations (ÁVO or ÁVH), an affair so remarkably depicted by Péter Esterházy in his acclaimed novel Javított kiadás [Revised Edition] (2002). Scholten mentions only in passing that some of his informants suspected that other members of the aristocracy could have been informants (225-6) but without supplying any names or examples.

This lack of critical treatment of Scholten's sources creates the impression that he is more charmed by aristocratic culture - its manners, pose, decor, clothing, pizzazz - than keen on a critical historical investigation of the aristocracy's role in this part of Central-Eastern Europe particularly in the twentieth century. This attitude is close to that of the Romanian nouveau rich whom Scholten ridicules for rebuilding the Bethlen-Haller Castle in its original medieval style (308-12). He also highlights cases in which some members of this aristocracy have successfully integrated into Western societies but remains silent about the less honorable facets of their lives. For example, he is quick to mention that a grandson of Karl Theodor von und zu Guttenberg became Minister of Defense in Germany in the late two thousands but says nothing at all about the plagiarism scandal surrounding this man's doctoral thesis that in 2011 put an end to his political ambitions.

In addition to the previously mentioned aspects, Scholten lumps together Romanian and Hungarian communism, which makes his argumentation simplistic in its lack of familiarity with the very different geo-political contexts of the two countries in the communist era and causes mistakes. For example, the amnesty of political prisoners in 1964 took place under Gheorghe Gheorghiu-Dej and not under Nicolae Ceauşescu (214); and János Kádár's so-called “goulash communism" (Lavinia Stan 2007) could hardly be compared to Ceauşescu's national communist 
course (Vladimir Tismaneanu 1984) that crippled Romania in the 1980s and made the country's transition to democracy after December 1989 very difficult. While I agree with Scholten that both Hungary and Romania are presently in dire need of social and political reforms in order to put an end to the nepotism and corruption ruling them to this day, I doubt that the aristocracy could be a central player in bringing in such a change. Returning to Scholten's opening statement that in embarking on this project he was ready to deal with potential attempts at mythmaking on the part of his aristocrat interviewees (20), it is disappointing that he ended up contributing to such mythmaking. This fascinating topic could have been made so much more valuable had he kept his initial promise to seriously investigate this mythmaking process and to scrutinize the aura surrounding Transylvanian past and present aristocracy. 